\title{
The role of B lymphocytes in the immuno-biology of non-small-cell lung cancer
}

\author{
Akshay J. Patel ${ }^{1} \cdot$ Alex Richter $^{1} \cdot$ Mark T. Drayson $^{1} \cdot$ Gary W. Middleton ${ }^{1,2} \mathbb{C}$ \\ Received: 14 November 2019 / Accepted: 22 December 2019 / Published online: 4 January 2020 \\ (c) The Author(s) 2020
}

\begin{abstract}
Tumour-infiltrating immune cells have been widely implicated to play a significant role in carcinogenesis, through both pro- or anti-tumour effects. The multi-faceted effects of lung cancer associated T lymphocytes have been extensively studied, and yet, the role of B lymphocytes remains an area less studied. In this review, we will describe the current understanding of the role of tumour-infiltrating B lymphocytes in NSCLC, discuss their prognostic significance, their functionality within the tumour microenvironment and ultimately how we might harness B-cell biology to develop B-cell therapeutic strategies in cancer.
\end{abstract}

Keywords B lymphocyte · Non-small-cell lung cancer (NSCLC) · Humoral Immunity · Immunoglobulin · Tumour -infiltrating B lymphocyte (TIL-B)

\section{Introduction}

Immune responses within the tumour microenvironment (TME) are important determinants of tumour behaviour, progression, and aggressiveness [1]. The role of T-cell-mediated immune responses in solid tumours is well established and has become the driving force for major therapeutic advances, specifically with the advent of immune checkpoint inhibitors [2]. The success of single agent and combination checkpoint blockade, which enables antigen-experienced microenvironmental $\mathrm{T}$ cells, has transformed the treatment paradigm of advanced NSCLC both as a front-line option and in the platinum-refractory setting. As a consequence, our understanding of the biology of these $\mathrm{T}$ cells has expanded exponentially. In contrast, our knowledge of B-cell biology in cancer is less well developed. Tumour-infiltrating B cells have been observed in all stages of lung cancer development, with their presence differing according to stage and histological subtype. Given that they play a role in both humoral and cellular immunity B-cell parameters may be important in

Gary W. Middleton

g.middleton@bham.ac.uk

1 Institute of Immunology and Immunotherapy (III), College of Medical and Dental Sciences, University of Birmingham, Vincent Drive, Birmingham B15 2TT, UK

2 School of Cancer Sciences, University of Birmingham, Birmingham, UK determining both responsiveness to and toxicity of checkpoint blockade. Manipulation of B-cell biology might offer significant immune-therapeutic opportunities [3]. Thus, understanding B-cell biology in NSCLC is of fundamental importance in informing potential novel multi-faceted approaches to favourably reset the immune contexture of the cancer microenvironment.

\section{B-cell ontogeny}

In the bone marrow, haematopoietic stem cells serve as the common lymphoid progenitor and continually give rise to $\mathrm{B}$ cells throughout life [4]. B-cell development and differentiation are subsequently regulated through the B-cell receptor (BCR). On leaving the bone marrow, B-cell development takes place in B-cell follicles within secondary lymphoid organs (SLOS), where germinal centres (GC) develop in response to antigen encounter. Mature B cells undergo a process known as somatic hypermutation (SHM), where enzyme induced mutations are introduced in the heavy and light chain variable regions to further diversify the immunological repertoire. The same enzyme mediates immunological class switch recombination (CSR), replacing the $\mu$ constant region for another heavy chain region to generate IgA, $\mathrm{IgE}$ or IgG. The cells with the highest affinity B-cell receptors (BCR) are positively selected (this requires signalling through the BCR for the cell to survive, negative selection 
occurs when the B-cell antigen receptor binds self-antigen and, therefore, undergoes cell death) and undergo clonal expansion in the germinal centre. These class-switched B cells can then give rise to long-lived plasma cells or memory B cells [5]. Germinal centres, which are normally found in SLOS such as the spleen and lymph nodes, can also occur as tertiary lymphoid structures (TLS) in tumours; this has been reported in colon, breast and NSCLC [6-8]. The de novo formation of ectopic lymphoid tissue can occur at the site of inflammation in potentially any organ system [9]. There is evidence that the adaptive immune system can be initiated independent of SLOS in these TLS in NSCLC [7].

\section{B-cell function}

\section{Antigen presentation}

T cell immune responses can be activated by B cells. Antigen-specific interactions require antigen internalisation via the BCR with subsequent presentation to T cells in an MHCrestricted manner [10]. Depleting host B cells from normal adult mice results in sub-optimal $\mathrm{CD} 4+\mathrm{T}$ cell activation during immune responses to low-dose foreign antigen [11]. Activated B cells derived from peripheral donor blood from healthy controls present antigens to $\mathrm{CD} 4+$ and $\mathrm{CD} 8+\mathrm{T}$ cells [12]. B cells and dendritic cells further provide a costimulatory signal which is critical to the expansion of an effector $\mathrm{T}$ cell population, namely the cross-linking of CD40 with CD154 (CD40 Ligand) on CD4 + T cells [10] which in turn induces the expression and thence stabilisation of CD86 (B7.2) and CD80 (B7.1) on the B-cell surface (second costimulatory signal).

\section{Antibody production}

B cells exist as long-lived plasma cells to produce antigenspecific antibody. The functional BCR can recognise an array of foreign antigens in the circulation and lymphoid organs, which then triggers antigen-specific antibody responses. Following antigen binding, BCR stimulation results in a signalling cascade mediated by membrane bound protein tyrosine kinases, Spleen Tyrosine Kinase (SYK), Bruton Tyrosine Kinase (BTK) and PI3K, in particular PI3K $\delta$ which is a p110 isoform with high lymphocyte specificity [4]. This in turn results in B-cell differentiation into plasma and memory cells. The plasma cells will traffic to the bone marrow or reside in SLOS, where they will continue to secrete antibody. BCR signalling controls this process from early B-cell precursor development to terminal plasma cell differentiation, long-lived IgG plasma cells are devoid of the BCR [5].

\section{Immunosuppression}

B cells play a vital role in the development of the immune system but are also responsible for immune homeostasis. Their immunosuppressive role has been illustrated by their ability to function as regulatory cells or Bregs, whereby they influence $\mathrm{T}$ cell differentiation and thus T-cell-mediated inflammatory responses through IL-10 production [13]. $B$ regulatory cells are associated with limiting excessive inflammation [14] and mice lacking IL-10 producing Bregs develop chronic inflammation [15]. IL-10 producing Bregs induce the Treg phenotype by skewing $\mathrm{T}$ cell differentiation in mice [16] and humans [17]. Other cytokines that have been implicated in B-cell specific immunosuppression are TGF-beta and IL-35. TGF-beta when produced by B cells can induce CD4 $+\mathrm{T}$ cell apoptosis [18] and CD8 $+\mathrm{T}$ cell anergy [19]. Chimaeric mice lacking either p35 or EBi3 (IL-35 subunits) in B cells develop accentuated autoimmune responses and have greater protection against Salmonella induced sepsis [20].

IL-10 has been useful for Breg characterisation in both mice and humans; however, this can be up or down-regulated during immune activation and is not a stable inducible trait $[14,21]$. A lineage-specific marker for Bregs equivalent to Foxp3 has not been identified. B cells are polarised to Bregs in response to microenvironmental cues: Bregs have been derived by treating human derived peripheral $\mathrm{B}$ cells with tumour-conditioned media; these Bregs were able to suppress the activity of human $T$ cells in vitro and they exhibited low surface expression of CD20 unlike healthy control human B cells [22, 23]. These tumours evoked Bregs did not utilise IL-10 dependent suppression but instead primarily functioned to promote the differentiation of Tregs (CD25+) via the TGF $\beta$ signalling axis [22].

\section{Pre-clinical studies of the role of B cells in cancer}

There appears to be a significant difference in the role of B cells in animal models which represent different stages in the development of cancer. In murine models of pre-malignancy, B cells appear to drive inflammation which in turn induces pre-malignancy.

\section{Pre-malignancy models}

Early evidence from the K14-HPV16 model (these RAG-1 knockout (KO) mice in which carcinogenesis is initiated by HPV lack T and B cells) has shown that the lack of an adaptive immune response results in failure to initiate 
leucocyte infiltration during pre-malignancy [24] and this halts progression towards carcinogenesis. Adoptive transfer of B lymphocytes or serum from HPV16 mice into HPV16/RAG1-/- mice resulted in significant infiltration of CD45 + leucocytes, macrophages and granulocytes in the dermal stroma as well as detectably higher levels of serum Ig which then enhanced malignant progression. In this model of squamous carcinogenesis, B cells were shown to play a role in activating $\mathrm{Fc} \gamma$ receptors ( $\mathrm{Fc} \gamma \mathrm{Rs}$ ) on resident and recruited myeloid cells likely via circulating immune complexes (CIC) detected in the serum of HPV16 mice and formed from IgG bound to cognate HPV16 antigens. These CICs were localised to both the epidermal and dermal components of neoplastic skin. The recruitment of these chronically activated leucocytes was dependent on Fc $\gamma R$ expression [25], as shown by the reduced level of inflammatory cell infiltration in neoplastic skin in FcyR-/- KO mice. Subsequently it was shown in K14-HPV16 mice that premalignant dysplasia could be prevented through B-cell depletion [26]. Administration of anti-CD20 monoclonal antibodies depleted B cells in peripheral blood and SLOS with resultant reduced levels of circulating $\operatorname{IgG}$, immune complex deposition and trafficking of myeloid cells (CD11+), CD45 + leucocytes, mast cells and GR1 + cells to neoplastic skin [26].

In a DMBA/TPA murine model of skin carcinogenesis adoptive transfer of B cells from DMBA/TPA wild type (WT) mice into TNF- $\alpha$ knockout mice significantly increased papilloma development $(p<0.05)$, an effect not seen when B cells from the TNF- $\alpha$ knockout mice were transferred to RAG2-/- mice [27]. TNF- $\alpha$ is a potent inflammatory cytokine and tumour promotor, Bregs are known producers of TNF- $\alpha$. Selective TNF- $\alpha$ deletion in CD19+-Cre B cells significantly reduced papilloma development compared to B cells from WT mice $(p<0.002)$. TNF- $\alpha$ knockout mice showed increased levels of IFN- $\gamma$ and $\mathrm{CD} 8+\mathrm{T}$ cell skin infiltration, but also a significant reduction in the number of splenic CD19+CD21hi, IL-10 producing Bregs compared with WT mice $(p<0.01)$. Further experimental data showed that TNF- $\alpha$ blockade of LPS-induced B-cell activation significantly reduced IL-10 production with no difference in IL-2, $-4,-5,-12$ or IFN- $\gamma$. The results of this study identify Bregs as contributory to squamous carcinogenesis, with their activity likely regulated by TNF-alpha with Bregs themselves acting as a cellular source of TNF- $\alpha$.

The impact of B cells in established cancer appears to be very different to their role in pre-malignant disease.

\section{Established cancer models}

B-cell depletion using anti-CD20 in a B16 melanoma murine model resulted in increased tumour burden and the development of pulmonary metastasis [28]. CpG (TLR 9 ligand) primed $\mathrm{B}$ cells caused tumour regressions in a B-cell deficient melanoma model [29]. CpG treatment of B cells induced higher expression of MHC class I and II as well as CD20. It was also noted that in the mice that underwent adoptive B-cell transfer, the lung tumours expressed significantly lower levels of BCL-2 (an anti-apoptotic protein) and increased levels of TRAIL (TNF-related-apoptosis-inducing-ligand, a pro-apoptotic protein), TRAIL expression is highest in germinal centre B cells and thus the upregulation in these murine lung tumours is likely B-cell driven [29].

In a $4 \mathrm{~T} 1$ breast cancer model treatment with an anti-CD20 antibody resulted in massive cancer growth and metastasis. Eradication of $\mathrm{CD} 20^{\mathrm{hi}} \mathrm{B}$ cells, enriched for a select population of $\mathrm{CD} 20^{\mathrm{LO}}$ Bregs which escaped CD20-directed depletion and thus significantly suppressed CD4 + and CD8 + T cell activity thus abrogating anti-tumour responses [23]. Targeted delivery of CpG-ODN to CXCR5 expressing cells, reversed the phenotype of these tumour evoked Bregs (which upregulated CD20) and restored effector B-cell responses. This was demonstrated by a complete abrogation of tumour metastasis in anti-CD20 treated $4 \mathrm{~T} 1.2$ cancer bearing mice after adoptive transfer of $\mathrm{CpG}$ treated $\mathrm{B}$ cells [30]. Using the same murine model, Tao et al. demonstrated that IL-10 inhibition significantly augmented the therapeutic efficacy of adoptive B-cell transfer, as demonstrated by increased trafficking of $\mathrm{CD} 8+\mathrm{T}$ cells into the tumour microenvironment as well as in vitro antigen-specific B-cell dependent, FasL-mediated tumour cell killing [31]. Activated B cells from this model produce IgG and mediate complementdependent tumour cell lysis in vitro [32]. Finally, the use of intra-tumoural TLR9 immune stimulation in combination with PD-1 blockade has demonstrated clinical efficacy in advanced melanoma, with increased B-cell infiltration noted on post-treatment tumour biopsies [33]. Phase I clinical trial data from patients with metastatic solid tumours showed a non-significant increase in TLR9-expressing naïve B cells during therapy [34].

\section{Tumour infiltrating B lymphocytes in human lung cancer}

Table 1 summarises studies that have identified TIL-Bs in tissue and examined their associated prognostic significance. These studies largely focus on NSCLC which is where the correlation between TIL-Bs and disease-specific outcome has been shown to be strongest by comparison with other forms of Lung cancer. However, groups have investigated the immune milieu in large cell carcinoma and Small Cell Lung Carcinoma (SCLC). In the former, Eerola et al. have demonstrated that TIL-Bs do correlate with better overall survival [35], whereas in SCLC, B-cell infiltration is significantly reduced compared with $\mathrm{CD} 8+\mathrm{T}$ cell 


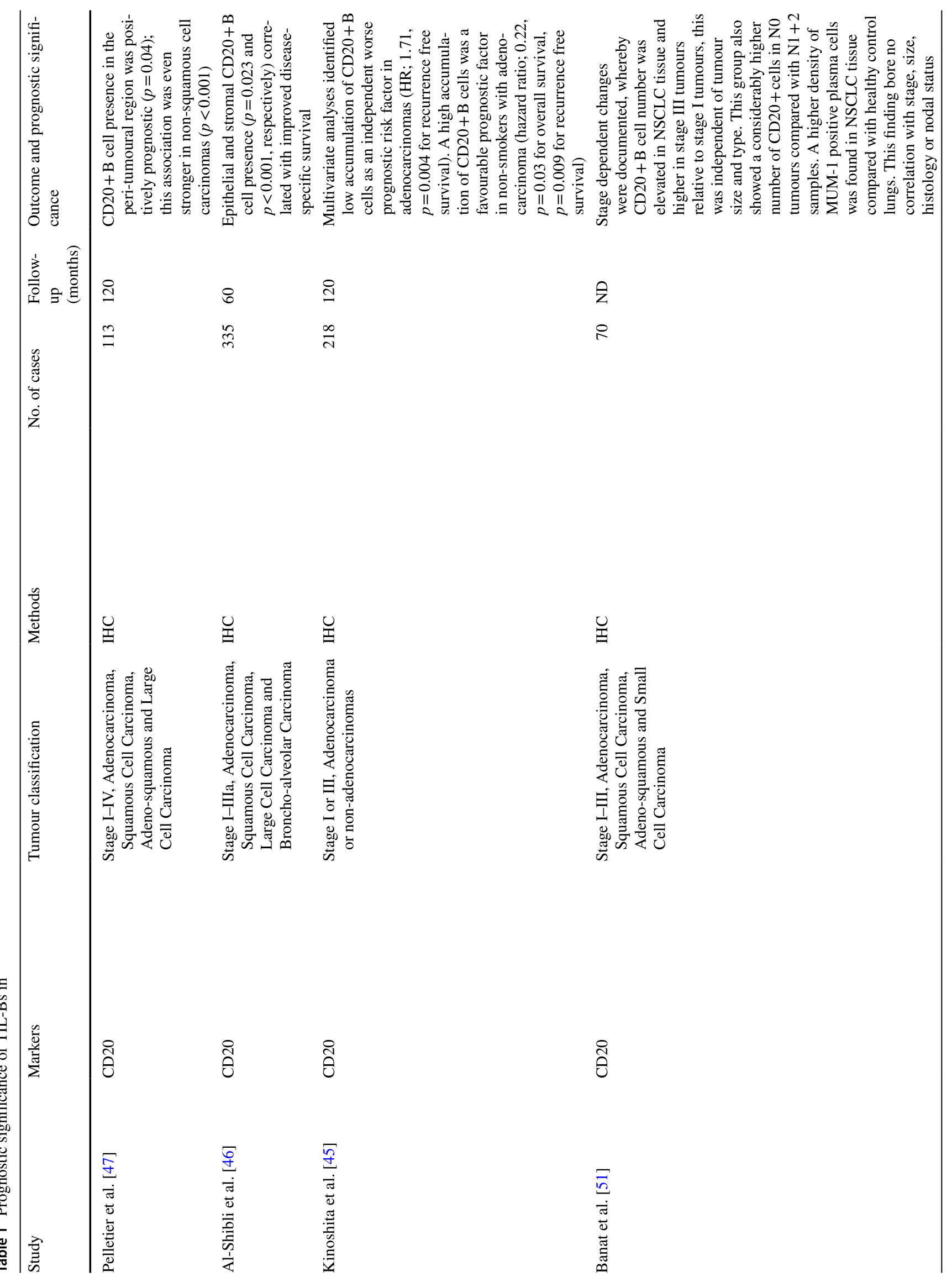




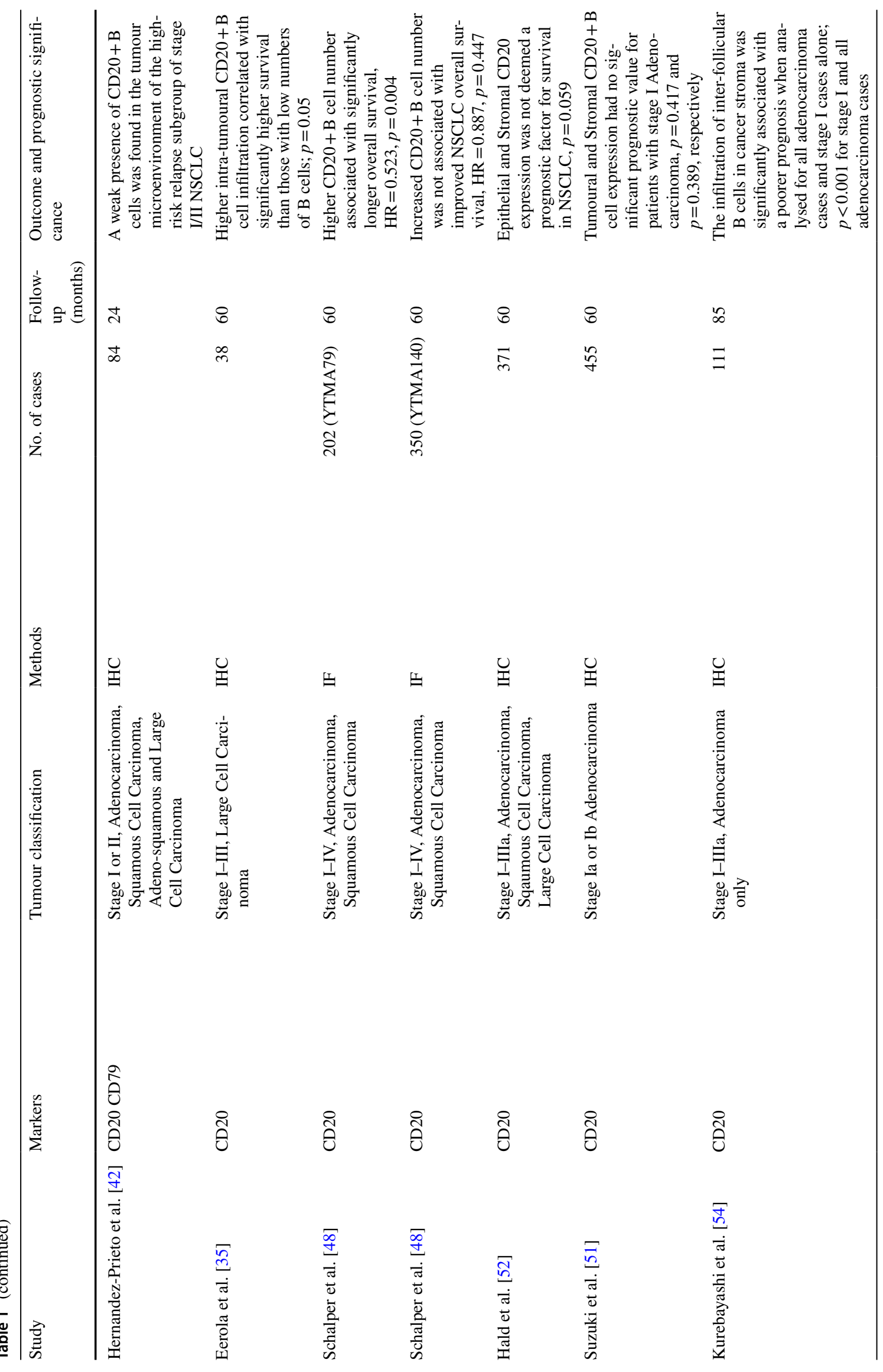




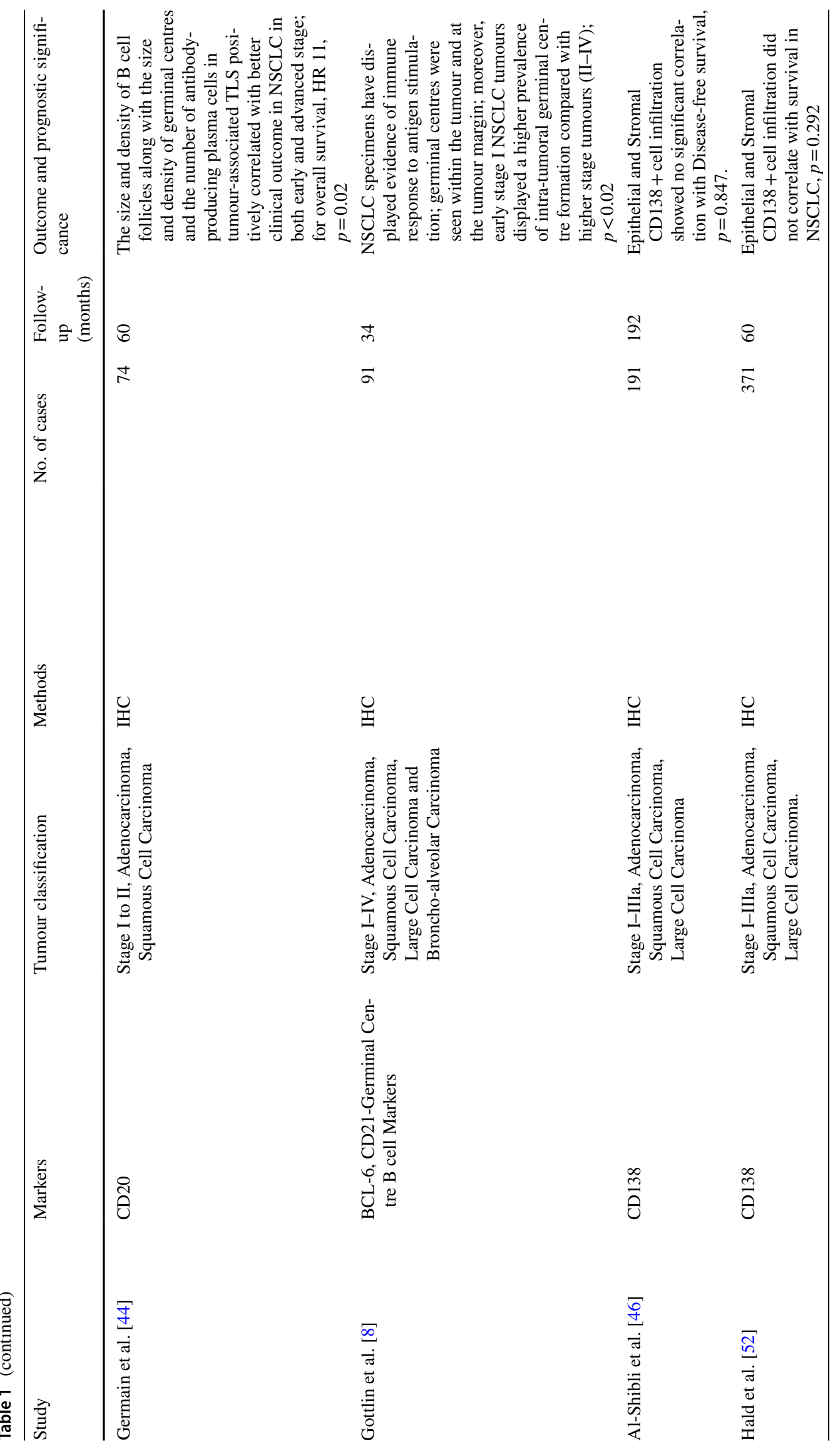




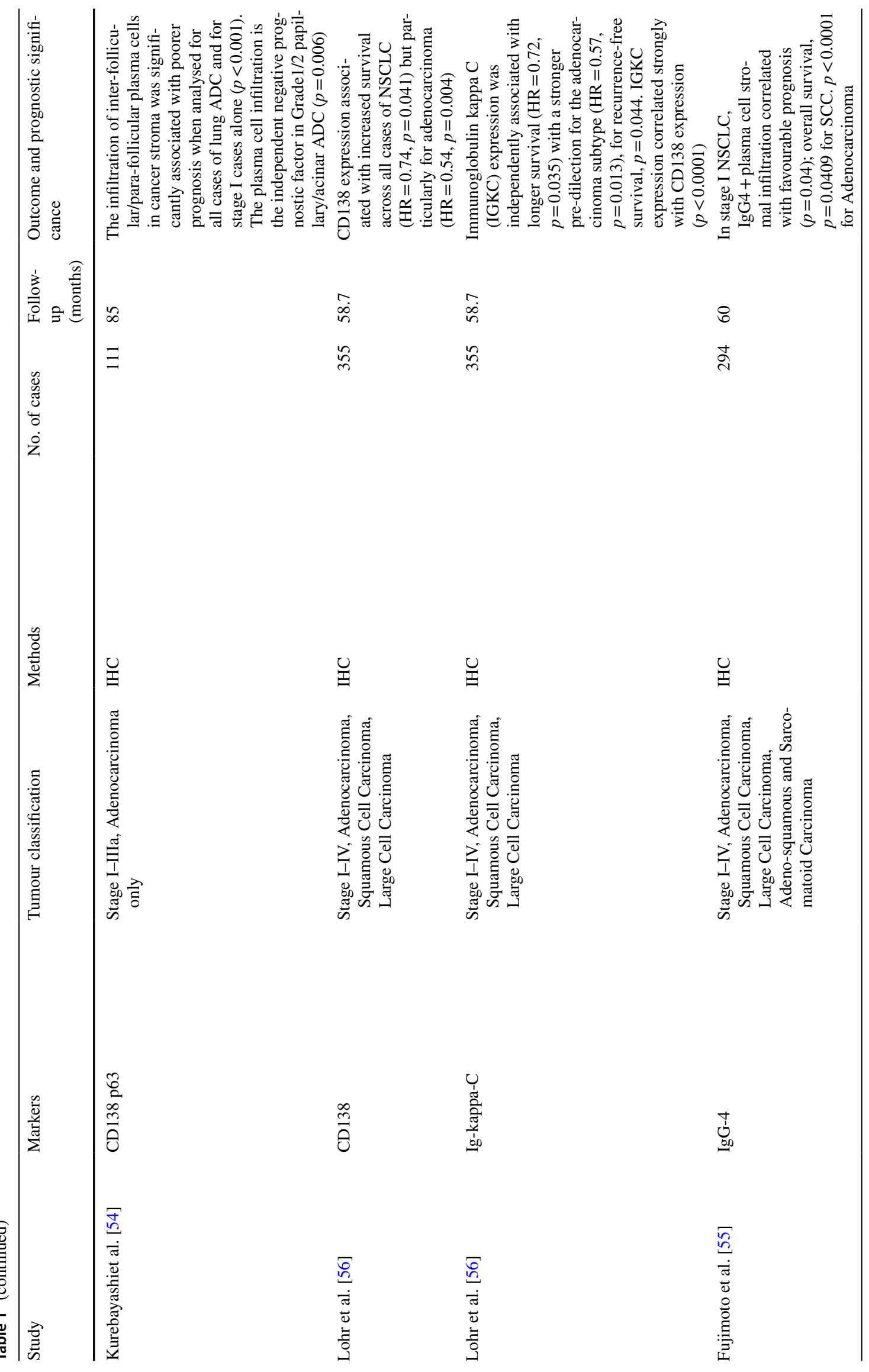




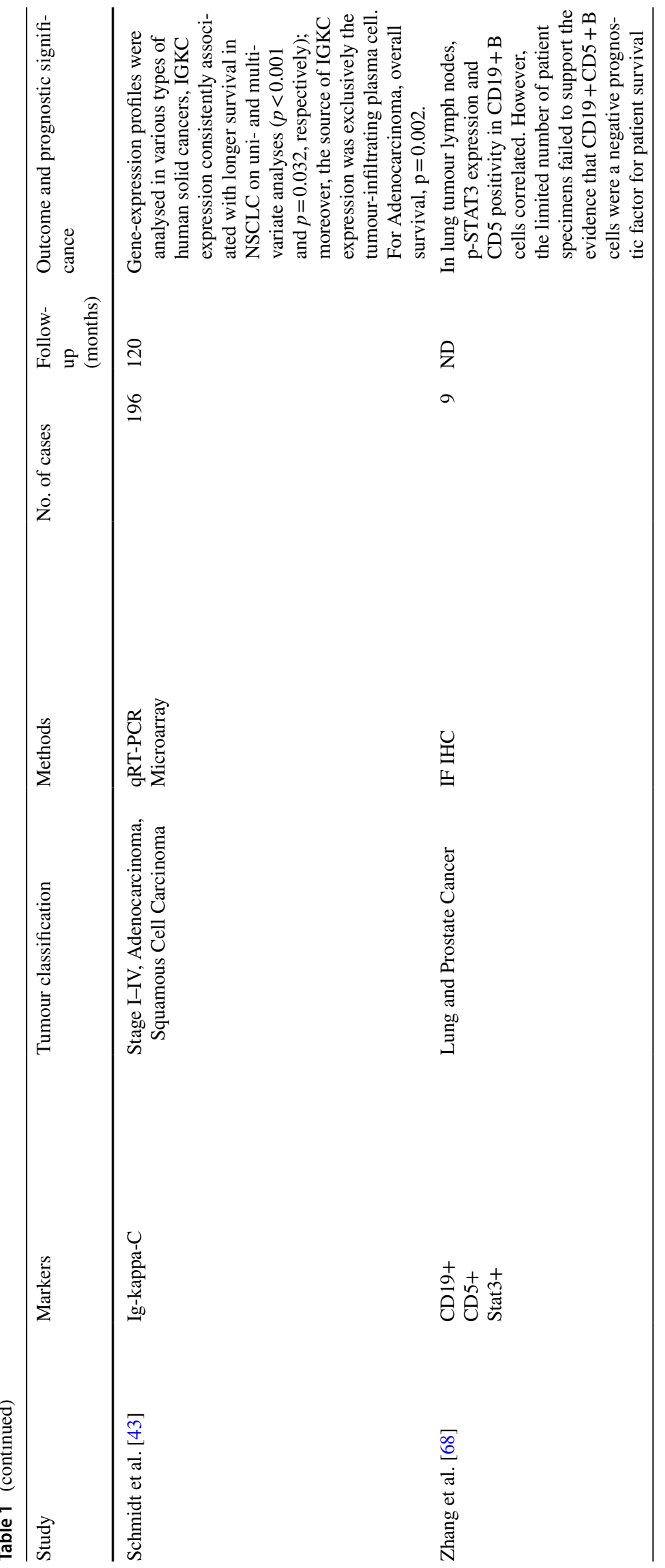

照 Springer 


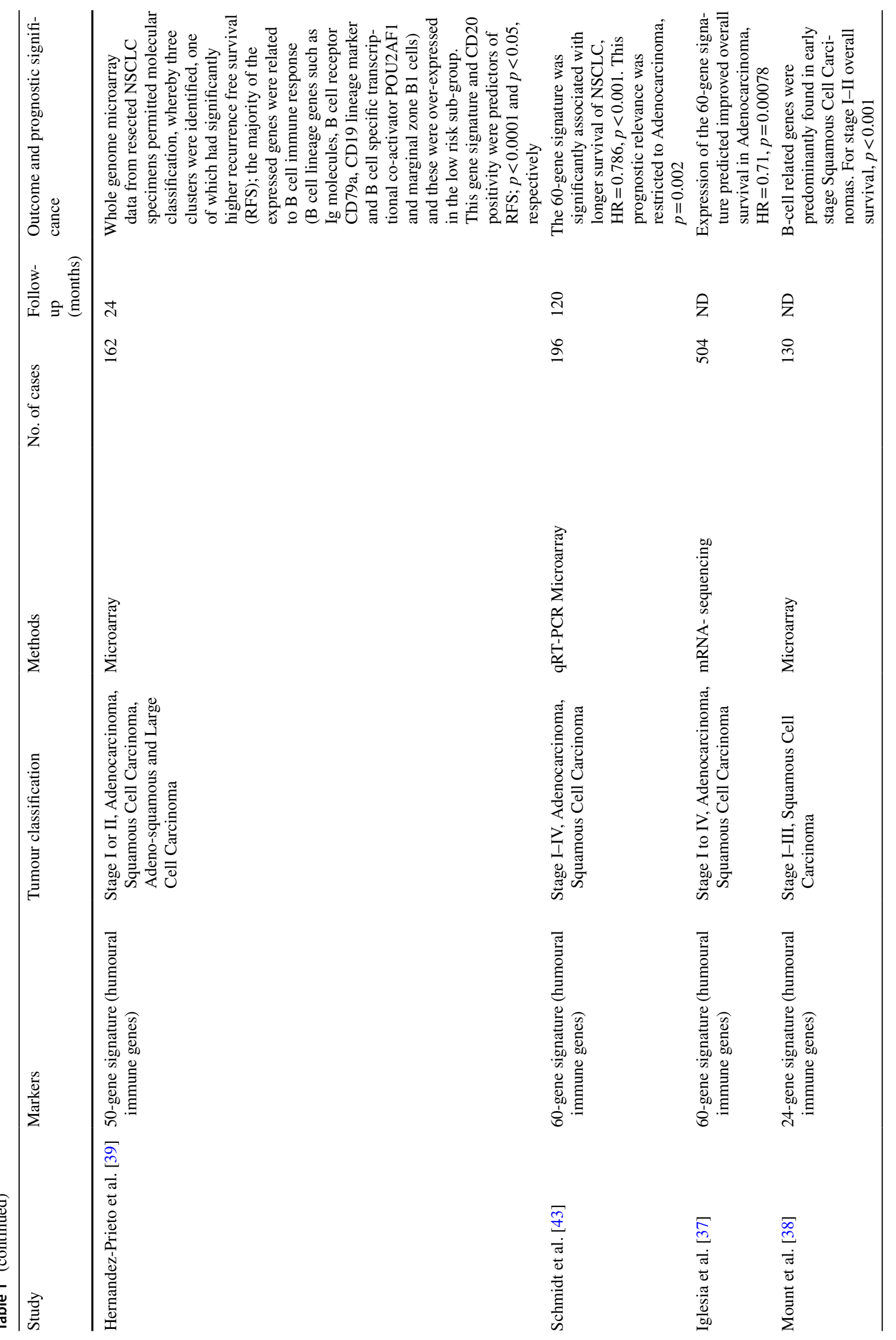




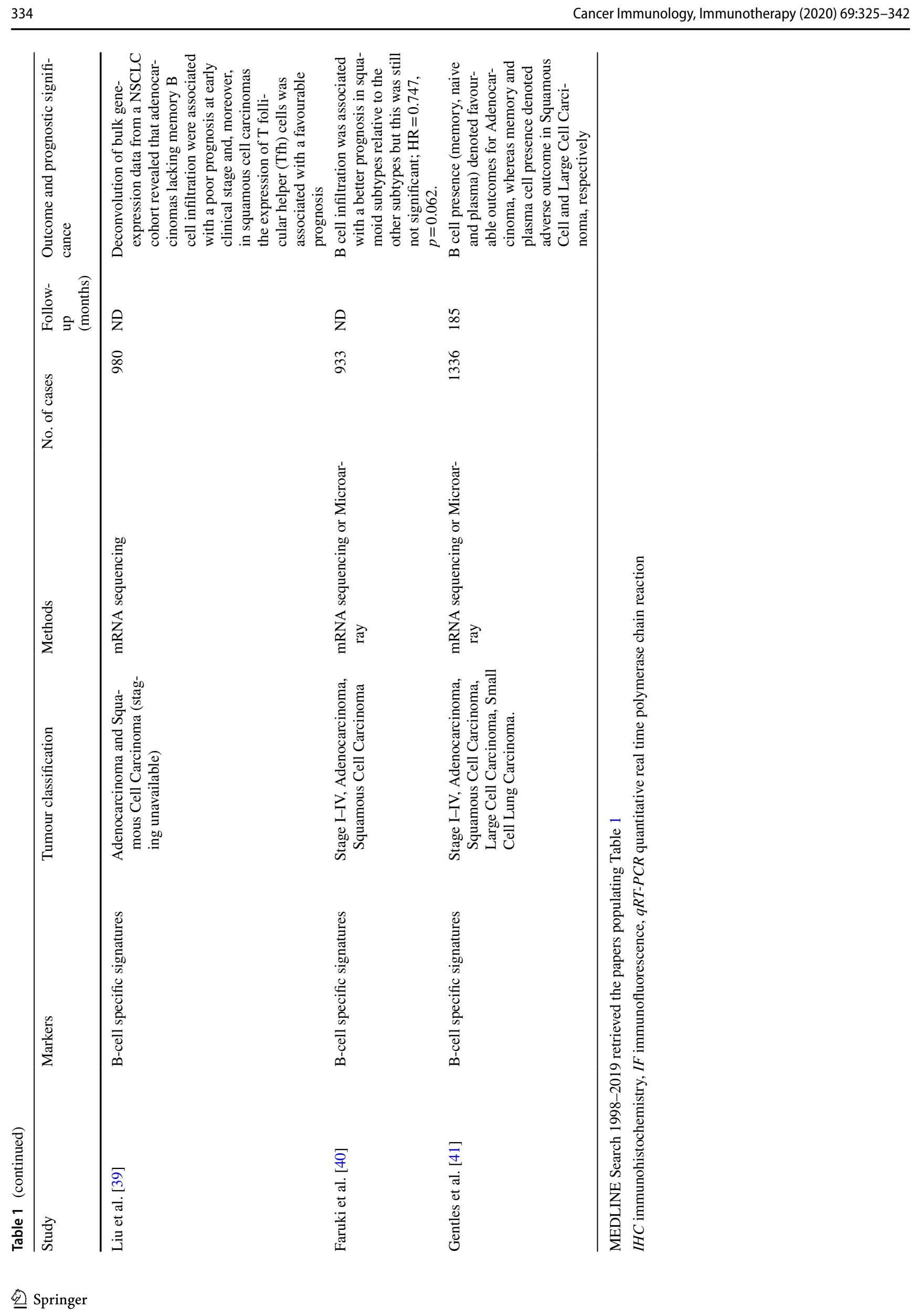


and Macrophage infiltration and TIL-B number has not been shown to associate with survival ( $p=0.634$ by $\log$ rank) [36].

In Table 1, the majority of studies have used a combination of immunofluorescence or immunohistochemistry to identify these cells in tissue. Of the 28 studies identified, 18 have used IHC as a primary method, mRNA sequencing has been employed in 4 studies and 2 have employed qtPCR [37-41]. An anti-BCL-6 antibody and an anti-CD21 antibody were utilised to identify Germinal Centre B cells and mature B cells, respectively. Immunohistochemistry was used to determine B-cell density, location and phenotype within NSCLC tissue [8]. Studies have utilised PCR microarray and Mrna-sequencing techniques to identify primarily humoral immunity related gene signatures in NSCLC specimens [42, 43]. CD20 + B-cell infiltration has been shown to be positively prognostic in NSCLC by a number of different groups [38-43]. Disease-free and overall survival was significantly higher in non-smokers with non-squamous NSCLC [45]. Significantly improved survival has also been shown in large cell carcinomas with higher degrees of CD20+B-cell infiltration [35]. Associations have been made between TLS (GCs forming as ectopic foci of follicular B cells and clusters of mature DC-Lamp ${ }^{+v e}$ Dendritic cells and T cells in cancer tissue, in response to antigen stimulation) in NSCLC and improved long-term survival. The presence of both types of antigen-presenting cells and mature dendritic cells in these TLS strongly predicts the outcome of patients [7, 44]. A low density of both follicular B cells and mature dendritic cells allows the identification of patients at high risk of poor survival. A higher prevalence of intra-tumoural GC formation was found in NSCLC stage I tumours compared with higher stage (II-IV) tumours $(p<0.02)$ [8]. In a recent study [49] the expression of a tumour-induced plasmablast-like B-cell signature (TIPB) was significantly correlated with the expression of CD8a signatures and the density of CD8 + cells. High expression of the TIPB signature was correlated with overall survival in the melanoma TCGA data set. Importantly, a cohort of melanoma patients treated with anti-CD20 antibodies, showed significant ontreatment down-regulation of the TIPB signature: the signature was highly correlated with tumour inflammatory score, interferon gamma and $\mathrm{T}$ cell effector signatures all of which significantly decreased on anti-CD20 therapy. There was a marked depletion in both CD4 + and CD8 + cell density at the invasive tumour-stroma margin and a reduction in the TLS area, an effect which was prolonged. In support of this data suggesting the importance of B cells in a successful anti-cancer immune response, long-term follow-up of CD20 depletion with Rituximab in patients with lymphoma, it was shown that CD20 depletion was an independent risk factor for the development of secondary solid tumour malignancy in both univariate and multivariate analyses [50].
Finally, the prognostic impact of follicular B cells was evaluated in two patient cohorts; early stage untreated NSCLC and advanced stage NSCLC treated with neoadjuvant chemotherapy. "Foll-B-Hi" patients had significantly prolonged survival in early stage disease, (97\% DFS at 4 years compared with $62 \%$ in the "Foll-B-Lo" group), and in advanced stage disease, a benefit was demonstrated albeit not significant (56 month median DFS compared with 23 months in the "Foll-B-Lo" group). The global increase in follicular B-cell density was associated with an overall increase in mature DC density. When the combined immune populations were taken into account and correlated with survival, "Foll-B-Hi/mDC-Lamp ${ }^{\mathrm{HI}}$ " patients had the highest median survival, $100 \%$ of early stage patients $(p<0.04)$ and $55 \%$ of advanced disease patients $(p=0.007)$ were alive after a follow-up of 50 and 60 months, respectively [44]. "Foll-B-Lo/mDC-Lamp ${ }^{\mathrm{LO}}$ " patients had the worst prognosis.

Some studies have not demonstrated a prognostic impact of B-cell density on NSCLC outcomes [48, 51-54]. However, it may be that the lack of prognostic impact may relate to the high density of Bregs in such studies and it would appear to be essential that Breg density be considered separately [48, 51, 52]. An explicit analysis of whether Breg density is negatively prognostic for outcome, however, has not been performed. Finally, the prognostic impact may be dependant not only on enumeration of the appropriate B-cell subsets (TIMPs, follicular) but also by enumeration of tumour-associated B cells in the appropriate compartment, as opposed to analysis of un-segmented tumoural B-cell density. Most B cells are found at the invasive tumour-stroma margin, and it is here that the cancer cells are likely to polarise B cells to the immune-stimulatory TIPB phenotype.

\section{B-cell functionality: human NSCLC}

\section{Antibody specificity and antigen presentation}

Tumour antigen-specific B-cell responses are evidenced by the production of tumour-specific antibody and the oligoclonality of TIL-Bs in the TLS [55]. B cells cultured from TLS' have been shown to produce tumour-specific IgG and IgA antibodies [44]. LAGE-1 was identified as the most immunogenic tumour antigen in NSCLC, followed by MAGE family antigens, p53 and NY-ESO-1 [44]. Plasma cell and Ig expression associates favourably with outcome in NSCLC [43, 56, 57]. IgG4 + plasma cell infiltration correlates favourably with prognosis [57].

In NSCLC tissue TIL-Bs present antigen to CD4 + TILs with resultant effector responses [55]. CD4 $+\mathrm{T}$ cells, B cells and DCs were co-cultured together with protein \pm costimulation with an anti-CD40/anti-CD28 antibody. AntiHLA-DR, -DP and -DQ was used to block MHC class II 
antigen presentation. $T$ cell responses were stratified according to "activated" (spontaneous presentation of antigen to CD4 + T cells), "antigen-associated" (presentation of antigen following re-stimulation by the antigen itself) and "nonresponsive". Activated TIL-Bs (CD19+CD20+CD69+C $\mathrm{D} 27+\mathrm{CD} 21+)$ and antigen-associated $\mathrm{B}$ cells mediated an effector T-cell response (IFN- $\gamma$ producing CD $4+\mathrm{T}$ cells). Conversely, exhausted phenotype TIL-Bs (CD19+CD20+ $\mathrm{CD} 69+\mathrm{CD} 27 \mathrm{~T}-\mathrm{CD} 21-)$ were associated with a regulatory T-cell phenotype (Foxp3 + CD4 + TILs) [55]. Exhausted TIL-Bs were still able to antigen present but controlled host damage from chronic antigen exposure by inducing a Treg phenotype and ultimately dampening anti-tumour immunity [55].

\section{Immunosuppression}

In NSCLC, significantly higher frequencies of peripheral Bregs (CD19+CD24 $\left.{ }^{\text {hi }} \mathrm{CD} 27+\right)$ and CD19+IL-10+B cells were detected compared with healthy controls [58].
IL-10 + B-cell infiltration has positively correlated with CD25 + Treg expression and advanced clinical stage [59]. Multiple subsets exist with similarities in effector function and phenotype; in humans $\mathrm{Br} 1$ cells $\left(\mathrm{CD} 19+\mathrm{CD} 25^{\mathrm{hi}}\right.$ CD71 ${ }^{\text {hi }}$ ) are strongly IL-10 positive. The differentiation of activated B cells into plasma cells is controlled by the expression of transcription factors, IRF4 and BLIMP-1 which are also critical for B-cell suppressive functions and some $\mathrm{T}$ cell suppressive functions (IRF4 expression in Tregs is dependent on Foxp3) [92]. B cells that co-express IRF4 and BLIMP-1 are the main source of B-cell derived IL-10 in vivo, and plasma cells are, therefore, a significant contributor, however, not all plasma cells produce IL-10 [60]. Currently, the signals that are required for differentiation into these regulatory B cells are not known.

Numerous studies have phenotypically characterised various Breg subsets in health and disease, this is displayed in Table $2[58,59,61-80]$. The findings from these studies of human Bregs in cancer underscores the ability of different Breg subsets to mediate immunosuppression in support of

Table 2 Human breg phenotypes in cancer and disease

\begin{tabular}{|c|c|c|c|}
\hline Phenotype & Mechanism of suppression & Disease process & Author \\
\hline \multirow{5}{*}{$\begin{array}{l}\text { CD19+ CD24hi CD38hi (Immature } \\
\text { subtype) }\end{array}$} & IL-10, PD-L1 & SLE & Blair et al. [61] \\
\hline & CD1d & SLE & Bosma et al. [62] \\
\hline & IL-10, TGF-P, CD40/CD40L & Hepatocellular carcinoma & Shao et al. [63] \\
\hline & TGF-P & Breast cancer, Gastric cancer & Olkhanud et al. [64], Wang et al. [65] \\
\hline & IL-10 & $\begin{array}{l}\text { Non-small cell lung cancer, } \\
\text { Oesophageal cancer, Ovarian } \\
\text { cancer }\end{array}$ & $\begin{array}{l}\text { Liu et al. [59], Qian et al. [66], Zhou } \\
\text { et al. [58], Wei et al. [67] }\end{array}$ \\
\hline \multirow[t]{2}{*}{$\mathrm{CD} 19+\mathrm{CD} 5+$} & IL-10, STAT3 & Lung, Prostate cancer & Zhang et al. [68] \\
\hline & IL-10, TGF-P & Breast cancer & Lee-Chang et al. [69] \\
\hline $\mathrm{CD} 19+\mathrm{CD} 5+\mathrm{CD} 1 \mathrm{dhi}$ & IL-10 & $\begin{array}{l}\text { Chronic inflammation within gut- } \\
\text { associated lymphoid tissue }\end{array}$ & $\begin{array}{l}\text { Yanaba et al. [70], Mizoguchi et al. } \\
\text { [71] }\end{array}$ \\
\hline $\mathrm{CD} 19+\mathrm{CD} 35+$ & IL-35 & Pancreatic Cancer & $\begin{array}{l}\text { Wang et al. [72], Pylayeva-Gupta } \\
\text { et al. [73] }\end{array}$ \\
\hline CD19+CD24hi CD27 + (B10 cells $)$ & IL-10 & $\begin{array}{l}\text { SLE, Rheumatoid arthritis, primary } \\
\text { Sjogren's Syndrome, Multiple } \\
\text { sclerosis, Autoimmune vesiculob- } \\
\text { ullous skin disease }\end{array}$ & Iwata et al. [74] \\
\hline $\begin{array}{l}\mathrm{CD} 19+\mathrm{CD} 38+\mathrm{CD} 1 \mathrm{~d}+\mathrm{IgM}+\mathrm{CD} 1 \\
47+(\mathrm{GrB}+\mathrm{B} \text { cells })\end{array}$ & IL-10, GranzymeB & $\begin{array}{l}\text { Breast, Ovarian, Cervical, Colorec- } \\
\text { tal, Prostatic carcinomas }\end{array}$ & Lindner et al. [75] \\
\hline $\begin{array}{l}\text { CD19+ CD25hi CD71hi CD73lo } \\
\text { (Br1 subtype) }\end{array}$ & IL-10, IgG4 & $\begin{array}{l}\text { Human model of allergic inflam- } \\
\text { mation in response to bee venom } \\
\text { antigen }\end{array}$ & van de Veen et al. [76] \\
\hline $\begin{array}{l}\text { CD19+CD24hi CD27int CD38hi } \\
\text { (Plasmablast subtype) }\end{array}$ & IL-10 & $\begin{array}{l}\text { Healthy human donor peripheral } \\
\text { blood }\end{array}$ & Matsumoto et al. [77] \\
\hline $\mathrm{CD} 39+\mathrm{CD} 73+$ & Adenosine & $\begin{array}{l}\text { Healthy human donor peripheral } \\
\text { blood }\end{array}$ & Saze et al. [78] \\
\hline (iBreg subtype) & TGF-P, IDO & $\begin{array}{l}\text { Healthy human donor peripheral } \\
\text { blood }\end{array}$ & Nouel et al. [80] \\
\hline CD19+ TIM-1+ & IL-10 & HIV-1 Infection & Liu et al. [79] \\
\hline
\end{tabular}

MEDLINE Search 2000-2019 retrieved the papers populating Table 2 
tumour growth through a variety of mechanisms; suppressive cytokine production (IL-10, TGF- $\beta$, IL-35), suppression of $\mathrm{T}$ cells and NK cells and the expansion of suppressive Tregs and myeloid-derived suppressor cells [30], expression of inhibitory ligands such as PD-L1 to dampen anti-tumour immunity [81] and STAT3 mediated promotion of angiogenesis and Treg augmentation [22, 68, 82]. It is unclear whether Bregs enhance tumour progression directly or if an increase in the Breg population is merely reflective of the immune response being mounted against the tumour [83].

\section{B-cell milieu in NSCLC}

B cells can exist in a continuum of naïve cells to terminally differentiated plasma cells within the TME and more specifically within the TLS [44]. Determining the ratio between these so-called "anti-tumour" TLS derived TIL-Bs and the "pro-tumour", inhibitory Bregs is important to understand the biology and long-term outcome from this disease. This balance is likely influenced by the microenvironmental cues which play a role in determining B-cell polarity. CXCL13 and Lymphotoxin have been identified as two factors critical to the formation and development of lymphoid follicles in the gut [84], and in lung cancer, B cells produce CXCL13 and Lymphotoxin via TLR4 signalling which acts as a positive feedback loop to support the formation and high density of TLS [85, 86]. CXCR5 expressing B cells stimulated by CXC13 coupled CpG-ODN can trigger the cytolytic effect of CD8 + T cells leading to the abrogation of metastasis in 4T1.2 tumour-bearing mice [23]. Resveratrol, Lipoxin, Glucosides of Paeony have also inhibited Bregs through STAT3 and/or ERK inactivation leading to a reduction in IL-10 and TGF- $\beta$ levels thus exerting an anti-tumour effect [87]. B-cell homeostasis and thus polarity will largely be determined by the degree of inflammation within the tumour, factors such as tissue hypoxia, intra-tumoural vascularity, cytokine milieu and cellular infiltration are all factors which are likely to exert control over the pro versus anti-tumour B-cell balance but as yet there is little evidence describing the Breg/B effector ratio in tumour biology, and this is likely due to the transient inducible nature of Bregs.

\section{The interplay of B cells and checkpoint blockade}

Immune checkpoint blockade antibodies have improved cancer therapy by overcoming the inhibition of $\mathrm{T}$ cell effector functions, yet a significant proportion of patients still do not respond to such therapies. In the first study to investigate whether B-cell density impacts outcome with checkpoint blockade, B-cell content was determined in
34 melanoma patients undergoing PD-1 blockade monotherapy and evaluated for response [88]. Dichotomising the patients at the median of CD20 positive cells in at least one histospot there was no difference in response or survival between those with high and low B-cell density. The comments made earlier about enumeration of specific B-cell populations in specific microenvironmental segments made earlier also apply here. B-cell depletion in the MC38 (colon carcinoma) and YUMMER1.7 (melanoma) models did not impact the efficacy of anti-PD-1 treatment. Anti-PD-1 outcomes were similar in $m u \mathrm{MT}$ mice (mice lacking B cells) and WT mice bearing MC38 tumours [88]. Larger data sets in other cancers need to be interrogated to fully understand whether there is any impact of specific intra-tumoural B-cell populations on the outcome of checkpoint blockade. This is particularly the case given earlier data showing that clinical benefit with ipilimumab was greater in melanoma patients with sero-positivity against NY-ESO [89]: as mentioned above, the CTags appear to be potent immunogens stimulating antibody responses. Furthermore, gene-expression profiling in urothelial carcinoma and melanoma patients undergoing both anti-PD-1/PD-L1 and anti-CTLA4 therapy identified a memory B-cell (MBL) signature which was significantly and reproducibly elevated in patients showing clinical benefit [90]. It significantly outperformed other immune cell signatures and remained significantly associated with outcome when including tumour mutational burden, copy number aberration burden and checkpoint expression. Samples enriched for an innate PD-1 resistance scores had significantly lower levels of MBL scores. The MBL score positively correlated with BCR heavy chain expression and the expression of $\mathrm{T}$ cell activation genes, MHC class II and genes responsible for B-cell proliferation and activation within the TME. Finally, high expression of the TIPB signature was associated with improved survival in melanoma patients treated with antiPD-1, and plasmablast-like and naïve B-cell frequencies were significantly higher in patients responding to immune checkpoint blockade [49]. The use of anti-PD-1 treatment in murine models has shown to increase total IgG and OVA-specific IgG production in OVA-immunised mice [91]. The enhanced humoural response in these mice is thought to be mediated by CD $4+\mathrm{ICOS}+\mathrm{T}$ cells which are presumably of the $\mathrm{T}$ follicular helper ( $\mathrm{Tfh}$ ) phenotype that go on to augment terminal B-cell differentiation in the germinal centre [91]. PD-1/PD-L1 interactions between Tfh and Bregs control this axis $[92,93]$ and by blocking this checkpoint, Tfh cells are released from Breg-induced suppression. This demonstrates the importance of heterogeneity of the B-cell repertoire and how checkpoint blockade can impact downstream immune responses by targeting select populations. Importantly, none of the above studies 
have examined B-cell density as predictive of response to checkpoint blockade in NSCLC or to combination chemo/ immunotherapy which has become a 1st line standard of care in this disease.

Given that PD-1 is expressed on B cells and can limit B-cell responsiveness [94, 95], and furthermore, the certain autoimmune conditions are mediated via auto-antibody formation, the association of B-cell sub-populations with checkpoint blockade toxicity has become a focus of investigation. Das et al. demonstrated in melanoma patients, a detectable decline in circulating B-cell numbers together with an increase in $\mathrm{CD} 21^{\mathrm{LO}} \mathrm{B}$ cells and plasmablasts after the first cycle of combination checkpoint blockade therapy [96]. These treatment induced changes in B-cell numbers preceded and correlated with both the frequency and timing of immune related adverse events (irAE). Early B-cell changes correlated with a higher rate of grade 3 or higher irAEs 6 months after starting treatment. Contrastingly, several groups have shown through case report series' that B-cell depletion therapy using Rituximab successfully treated B-cell-mediated irAEs in NSCLC [97, 98], SCLC [99], Melanoma [100] and Urothelial Carinoma [101]. This recapitulates the idea of B-cell enumeration and selective targeting of certain microenvironmental B-cell populations. Bregs which by nature are immunosuppressive and dampen down inflammation would limit anti-tumour activity in response to PD-1 blockade but effector B-cell populations with robust humoural responses and $\mathrm{T}$ cell activation mechanisms are driving autoimmunity and irAE in response to PD-1 blockade. These intriguing analyses need to be validated, extended and applied to other cancers amenable to checkpoint blockade and the mechanisms underlying these observations identified.

\section{Conclusions}

Studies in mouse models of pre-malignancy suggest that B-cell-mediated inflammation may be important in promoting the progression to invasive malignancy. Given the huge promise of reversing the pre-malignant phenotype to reduce the cancer burden, there is an urgent need to understand the role of B cells in human metaplasia, dysplasia and in situ cancer and how they mediate progression through these stages to decide whether B-cell-directed strategies may be of value in reducing the progression of pre-malignancy.

Studies examining B cells with a regulatory phenotype (Bregs) consistently suggest that Breg infiltration may enhance tumour progression. The factors that induce Bregs in human malignancy need to be defined. Specifically are there particular microbes, TLR ligands or cancer cell produced cytokines in the TME that polarise $\mathrm{B}$ cells to a Breg phenotype [14, 102]. Currently used B-cell depleting antibodies cannot distinguish between effector and regulatory B-cell subsets; therefore, meticulous phenotypic characterisation and study of this subset in the TME [14, 102] is required to identify Breg specific targets that can be exploited to selectively deplete Breg populations but more fundamentally to fully understand the role of Bregs in human cancer. There are some current potential anti-Breg strategies. In vivo murine studies have displayed selective Breg depletion using LXA4 without affecting conventional B-cell proliferation, differentiation and germinal centre formation thus promoting anti-tumour responses [87]. An alternate to Breg depletion would be repolarisation of this subpopulation into B effector cells, as has been shown with TLR9 ligands in vitro [22, 23]. Adoptive transfer of CpGpulsed $\mathrm{B}$ cells with effector phenotypes into patients with established cancer could be employed to shift the balance in favour of an anti-tumour B-cell response within the TME.

More work is needed to understand the anti-tumour impact of antibodies against tumour associate antigens, particularly CTags which appear to be strong immunogens, and to identify new humoural immunity targets. The disappointing results of the MAGRIT trial vaccinating NSCLC patients in the adjuvant setting [103] should not be taken as suggesting that harnessing the anti-tumour antibody response should be deprioritised: mono-epitopic vaccination as cancer therapy has a long history of failure. Multi-valent vaccines, preferably against personalised B-cell antigens, are one option. Building on the model of the chimaeric antigen receptor $\mathrm{T}$ cells (CART), highly specific B-cell receptors to critical tumour antigens could be cloned into autologous B cells and transferred into patients with resultant high specificity and high affinity anti-tumour Ig production. Alternatively, antibodies could be produced ex vivo and adoptively transferred. Given the role of B-cell PD-1 expression in mediating B-cell hypo-responsiveness, the role of PD-1 blockade in augmenting these strategies should be explored, as a research priority. Understanding B-cell biology will help to refine the understanding behind the effects of checkpoint blockade on the immune milieu. Toxicity from these therapies is the Achilles heel of this treatment strategy. As was alluded to earlier, work in mice and humans has demonstrated that PD-L1 ${ }^{\text {hi }}$ Bregs play a role in the suppression of humoral immunity through Tfh cell regulation; moreover, these cells are resistant to classical anti-CD20 therapy [93]. Firmly understanding the ontogeny of these B cells and their relationship to other B-cell subsets, including other Breg phenotypes is of paramount importance if we hope to be able to refine therapeutic strategies so as to augment anti-tumour protective immunity and dampen down autoimmune and hence toxic responses.

Finally, large scale prospective and careful B-cell subtype specific and microenvironment segment specific analyses are required in lung cancer and in other cancers 
to clarify the role of B cells in modulating the responsiveness to checkpoint blockade and in mediating the toxicity to these therapies. These studies will define the role of B-celltargeted strategies in augmenting the activity of, reducing resistance to and the ameliorating toxicity of this crucial class of anti-cancer agents.

Acknowledgements Review article, therefore, not applicable.

Author contributions AJP designed the manuscript layout and collected the material and data necessary to construct the article, as well as writing the article. GWM, AR, and MTD provided supervisory support and constructive critique of the article to enable revisions.

Funding No relevant funding to declare.

Availability of data and materials All data and materials used in constructing this manuscript can be found through a Medline search using Pubmed, all data is referenced in the section below.

\section{Compliance with ethical standards}

Conflict of interest The authors declare that there are no competing interests, financial or otherwise, in relation to the work described.

Ethical approval This article does not contain any studies with human participants or animals performed by any of the authors. Informed consent, therefore, was not an issue.

Informed consent Informed consent, therefore, was not an issue.

Open Access This article is licensed under a Creative Commons Attribution 4.0 International License, which permits use, sharing, adaptation, distribution and reproduction in any medium or format, as long as you give appropriate credit to the original author(s) and the source, provide a link to the Creative Commons licence, and indicate if changes were made. The images or other third party material in this article are included in the article's Creative Commons licence, unless indicated otherwise in a credit line to the material. If material is not included in the article's Creative Commons licence and your intended use is not permitted by statutory regulation or exceeds the permitted use, you will need to obtain permission directly from the copyright holder. To view a copy of this licence, visit http://creativecommons.org/licenses/by/4.0/.

\section{References}

1. Suzuki K, Kachala SS, Kadota K, Shen R, Mo Q, Beer DG et al (2011) Prognostic immune markers in non-small cell lung cancer. Clin Cancer Res Off J Am Assoc Cancer Res. 17(16):5247-5256

2. Palucka AK, Coussens LM (2016) The basis of oncoimmunology. Cell 164(6):1233-1247

3. Wang S, Liu W, Ly D, Xu H, Qu L, Zhang L (2018) Tumor-infiltrating B cells: their role and application in anti-tumor immunity in lung cancer. Cell Mol Immunol 8:1

4. Burger JA, Wiestner A (2018) Targeting B cell receptor signalling in cancer: preclinical and clinical advances. Nat Rev Cancer 18(3):148-167

5. Shaffer AL, Lin KI, Kuo TC, Yu X, Hurt EM, Rosenwald A et al (2002) Blimp-1 orchestrates plasma cell differentiation by extinguishing the mature B cell gene expression program. Immunity $17(1): 51-62$

6. Pagès F, Sanchez-Cabo F, Mlecnik B, Kirilovsky A, Nilsson M, Damotte D, et al (2005) Effector memory T cells, early metastasis, and survival in colorectal cancer. $\mathrm{N}$ Engl $\mathrm{J}$ Med 353(25):2654-2666

7. Dieu-Nosjean M-C, Antoine M, Danel C, Heudes D, Wislez M, Poulot V et al (2008) Long-term survival for patients with nonsmall-cell lung cancer with intratumoral lymphoid structures. J Clin Oncol Off J Am Soc Clin Oncol. 26(27):4410-4417

8. Gottlin EB, Bentley RC, Campa MJ, Pisetsky DS, Herndon JE, Patz EF (2011) The Association of intratumoral germinal centers with early-stage non-small cell lung cancer. J Thorac Oncol Off Publ Int Assoc Study Lung Cancer. 6(10):1687-1690

9. Drayton DL, Liao S, Mounzer RH, Ruddle NH (2006) Lymphoid organ development: from ontogeny to neogenesis. Nat Immunol 7(4):344-353

10. Janeway CA, Ron J, Katz ME (1987) The B cell is the initiating antigen-presenting cell in peripheral lymph nodes. J Immunol Baltim Md 1950 138(4):1051-1055

11. Bouaziz J-D, Yanaba K, Venturi GM, Wang Y, Tisch RM, Poe JC et al (2007) Therapeutic B cell depletion impairs adaptive and autoreactive CD4 + T cell activation in mice. Proc Natl Acad Sci 104(52):20878-20883

12. Rodríguez-Pinto D (2005) B cells as antigen presenting cells. Cell Immunol 238(2):67-75

13. LeBien TW, Tedder TF (2008) B lymphocytes: how they develop and function. Blood 112(5):1570-1580

14. Rosser EC, Mauri C (2015) Regulatory B cells: origin, phenotype, and function. Immunity 42(4):607-612

15. Fillatreau S, Sweenie CH, McGeachy MJ, Gray D, Anderton SM (2002) B cells regulate autoimmunity by provision of IL-10. Nat Immunol 3(10):944-950

16. Carter NA, Vasconcellos R, Rosser EC, Tulone C, MunozSuano A, Kamanaka M et al (2011) Mice Lacking Endogenous IL-10-Producing Regulatory B Cells Develop Exacerbated Disease and Present with an Increased Frequency of Th1/Th17 but a Decrease in Regulatory T Cells. J Immunol. 186(10):5569-5579

17. Flores-Borja F, Bosma A, Ng D, Reddy V, Ehrenstein MR, Isenberg DA et al (2013) CD19 + CD24hiCD38hi B cells maintain regulatory T cells while limiting TH1 and TH17 differentiation. Sci Transl Med. 5(173):173ra23

18. Tian J, Zekzer D, Hanssen L, Lu Y, Olcott A, Kaufman DL (2001) Lipopolysaccharide-activated B cells down-regulate Th1 immunity and prevent autoimmune diabetes in nonobese diabetic mice. J Immunol 167(2):1081-1089

19. Parekh VV, Prasad DVR, Banerjee PP, Joshi BN, Kumar A, Mishra GC (2003) B cells activated by lipopolysaccharide, but not by anti-Ig and anti-CD40 antibody, induce anergy in CD $8+T$ cells: role of TGF-1. J Immunol. 170(12):5897-5911

20. Shen P, Roch T, Lampropoulou V, O'Connor RA, Stervbo U, Hilgenberg E et al (2014) IL-35-producing B cells are critical regulators of immunity during autoimmune and infectious diseases. Nature 507(7492):366-370

21. Lighaam LC, Unger PPA, Vredevoogd DW, Verhoeven D, Vermeulen E, Turksma AW et al (2018) In vitro-induced human IL-10 + B Cells do not show a subset-defining marker signature and plastically co-express IL-10 with pro-inflammatory cytokines. Front Immunol. 9:1913

22. Olkhanud PB, Damdinsuren B, Bodogai M, Gress RE, Sen R, Wejksza $\mathrm{K}$ et al (2011) Tumor-evoked regulatory b cells promote breast cancer metastasis by converting resting CD $4+\mathrm{T}$ cells to T-regulatory cells. Cancer Res 71(10):3505-3515

23. Bodogai M, Lee Chang C, Wejksza K, Lai J, Merino M, Wersto RP et al (2013) Anti-CD20 antibody promotes cancer escape via 
enrichment of tumor-evoked regulatory B cells expressing low levels of CD20 and CD137L. Cancer Res 73(7):2127-2138

24. de Visser KE, Korets LV, Coussens LM (2005) De novo carcinogenesis promoted by chronic inflammation is B lymphocyte dependent. Cancer Cell 7(5):411-423

25. Andreu P, Johansson M, Affara NI, Pucci F, Tan T, Junankar $S$ et al (2010) FcRgamma activation regulates inflammationassociated squamous carcinogenesis. Cancer Cell 17(2):121-134

26. Affara NI, Ruffell B, Medler TR, Gunderson AJ, Johansson M, Bornstein S et al (2014) B cells regulate macrophage phenotype and response to chemotherapy in squamous carcinomas. Cancer Cell 25(6):809-821

27. Schioppa T, Moore R, Thompson RG, Rosser EC, Kulbe H, Nedospasov $S$ et al (2011) B regulatory cells and the tumorpromoting actions of TNF- $\alpha$ during squamous carcinogenesis. Proc Natl Acad Sci USA 108(26):10662-10667. https://doi. org/10.1073/pnas.1100994108

28. DiLillo DJ, Yanaba K, Tedder TF (2010) B cells are required for optimal CD4 + and CD8 + T cell tumor immunity: therapeutic B cell depletion enhances B16 melanoma growth in mice. J Immunol. 184(7):4006-4016

29. Sorrentino R, Morello S, Forte G, Montinaro A, De Vita G, Luciano A et al (2011) B cells contribute to the antitumor activity of CpG-oligodeoxynucleotide in a mouse model of metastatic lung carcinoma. Am J Respir Crit Care Med 183(10):1369-1379

30. Bodogai M, Moritoh K, Lee-Chang C, Hollander CM, Sherman-Baust CA, Wersto RP et al (2015) Immunosuppressive and prometastatic functions of myeloid-derived suppressive cells rely upon education from tumor-associated B cells. Cancer Res 75(17):3456-3465

31. Tao H, Lu L, Xia Y, Dai F, Wang Y, Bao Y et al (2015) Antitumor effector B cells directly kill tumor cells via the Fas/FasL pathway and are regulated by IL-10. Eur J Immunol 45(4):999-1009

32. Li Q, Lao X, Pan Q, Ning N, Yet J, Xu Y et al (2011) Adoptive transfer of tumor reactive $\mathrm{B}$ cells confers host $\mathrm{T}$ cell immunity and tumor regression. Clin Cancer Res Off J Am Assoc Cancer Res. 17(15):4987-4995

33. Ribas A, Medina T, Kummar S, Amin A, Kalbasi A, Drabick JJ et al (2018) SD-101 in combination with pembrolizumab in advanced melanoma: results of a phase $\mathrm{Ib}$, multicenter study. Cancer Discov 8(10):1250-1257

34. Weihrauch MR, Richly H, von Bergwelt-Baildon MS, Becker HJ, Schmidt M, Hacker UT et al (2015) Phase I clinical study of the toll-like receptor 9 agonist MGN1703 in patients with metastatic solid tumours. Eur J Cancer 51(2):146-156

35. Eerola A, Soini Y, Paakko P (1999) Tumour infiltrating lymphocytes in relation to tumour angiogenesis, apoptosis and prognosis in patients with large cell lung carcinoma. Lung Cancer. 26(2):73-83

36. Eerola AK, Soini Y, Pääkkö P (2000) A high number of tumorinfiltrating lymphocytes are associated with a small tumor size, low tumor stage, and a favorable prognosis in operated small cell lung carcinoma. Clin Cancer Res Off J Am Assoc Cancer Res. 6(5):1875-1881

37. Iglesia MD, Parker JS, Hoadley KA, Serody JS, Perou CM, Vincent BG (2016) Genomic analysis of immune cell infiltrates across 11 tumor types. J Natl Cancer Inst. 108(11):djw144

38. Mount DW, Putnam CW, Centouri SM, Manziello AM, Pandey $\mathrm{R}$, Garland LL et al (2014) Using logistic regression to improve the prognostic value of microarray gene expression data sets: application to early-stage squamous cell carcinoma of the lung and triple negative breast carcinoma. BMC Med Genom [Internet]. https://doi.org/10.1186/1755-8794-7-33

39. Liu X, Wu S, Yang Y, Zhao M, Zhu G, Hou Z (2017) The prognostic landscape of tumor-infiltrating immune cell and immunomodulators in lung cancer. Biomed Pharmacother Biomed Pharmacother 95:55-61

40. Faruki H, Mayhew GM, Serody JS, Hayes DN, Perou CM, LaiGoldman M (2017) Lung adenocarcinoma and squamous cell carcinoma gene expression subtypes demonstrate significant differences in tumor immune landscape. J Thorac Oncol Off Publ Int Assoc Study Lung Cancer 12(6):943-953

41. Gentles AJ, Newman AM, Liu CL, Bratman SV, Feng W, Kim D et al (2015) The prognostic landscape of genes and infiltrating immune cells across human cancers. Nat Med 21(8):938-945

42. Hernández-Prieto S, Romera A, Ferrer M, Subiza JL, LópezAsenjo JA, Jarabo JR et al (2015) A 50-gene signature is a novel scoring system for tumor-infiltrating immune cells with strong correlation with clinical outcome of stage I/II non-small cell lung cancer. Clin Transl Oncol 17(4):330-338

43. Schmidt M, Hellwig B, Hammad S, Othman A, Lohr M, Chen $\mathrm{Z}$ et al (2012) A comprehensive analysis of human gene expression profiles identifies stromal immunoglobulin $\kappa \mathrm{C}$ as a compatible prognostic marker in human solid tumors. Clin Cancer Res Off J Am Assoc Cancer Res. 18(9):2695-2703

44. Germain C, Gnjatic S, Tamzalit F, Knockaert S, Remark R, Goc J et al (2014) Presence of B cells in tertiary lymphoid structures is associated with a protective immunity in patients with lung cancer. Am J Respir Crit Care Med 189(7):832-844

45. Kinoshita T, Muramatsu R, Fujita T, Nagumo H, Sakurai T, Noji $S$ et al (2016) Prognostic value of tumor-infiltrating lymphocytes differs depending on histological type and smoking habit in completely resected non-small-cell lung cancer. Ann Oncol 27(11):2117-2123

46. Al-Shibli KI, Donnem T, Al-Saad S, Persson M, Bremnes RM, Busund L-T (2008) Prognostic effect of epithelial and stromal lymphocyte infiltration in non-small cell lung cancer. Clin Cancer Res Off J Am Assoc Cancer Res 14(16):5220-5227

47. Pelletier MP, Edwardes MD, Michel RP, Halwani F, Morin JE (2001) Prognostic markers in resectable non-small cell lung cancer: a multivariate analysis. Can J Surg J Can Chir. 44(3):180-188

48. Schalper KA, Brown J, Carvajal-Hausdorf D, McLaughlin J, Velcheti V, Syrigos KN, et al (2015) Objective Measurement and Clinical Significance of TILs in Non-Small Cell Lung Cancer. JNCI J Natl Cancer Inst [Internet]. 107(3). https:// academic.oup.com/jnci/article-lookup/doi/10.1093/jnci/dju435

49. Griss J, Bauer W, Wagner C, Simon M, Chen M, GrabmeierPfistershammer K et al (2019) B cells sustain inflammation and predict response to immune checkpoint blockade in human melanoma. Nat Commun 10(1):4186

50. Tarella C, Passera R, Magni M, Benedetti F, Rossi A, Gueli A et al (2010) Risk Factors for the Development of Secondary Malignancy After High-Dose Chemotherapy and Autograft, With or Without Rituximab: A 20-Year Retrospective FollowUp Study in Patients With Lymphoma. J Clin Oncol. https:// doi.org/10.1200/JCO.2010.28.9777

51. Suzuki K, Kadota K, Sima CS, Nitadori J, Rusch VW, Travis WD et al (2013) Clinical Impact of Immune Microenvironment in Stage I Lung Adenocarcinoma: tumor Interleukin-12 Receptor $\beta 2$ (IL-12R $\beta 2$ ), IL-7R, and Stromal FoxP3/CD3 Ratio Are Independent Predictors of Recurrence. J Clin Oncol 31(4):490-498

52. Hald SM, Bremnes RM, Al-Shibli K, Al-Saad S, Andersen S, Stenvold H et al (2013) CD4/CD8 co-expression shows independent prognostic impact in resected non-small cell lung cancer patients treated with adjuvant radiotherapy. Lung Cancer 80(2):209-215

53. Banat G-A, Tretyn A, Pullamsetti SS, Wilhelm J, Weigert A, Olesch C et al (2015) Immune and inflammatory cell composition of human lung cancer stroma. PLoS One 10(9):e0139073 
54. Kurebayashi Y, Emoto K, Hayashi Y, Kamiyama I, Ohtsuka $\mathrm{T}$, Asamura $\mathrm{H}$ et al (2016) Comprehensive immune profiling of lung adenocarcinomas reveals four immunosubtypes with plasma cell subtype a negative indicator. Cancer Immunol Res 4(3):234-247

55. Bruno TC, Ebner PJ, Moore BL, Squalls OG, Waugh KA, Eruslanov EB et al (2017) Antigen-presenting intratumoral B cells affect CD4 + TIL phenotypes in non-small cell lung cancer patients. Cancer Immunol Res 5(10):898-907

56. Lohr M, Edlund K, Botling J, Hammad S, Hellwig B, Othman A et al (2013) The prognostic relevance of tumour-infiltrating plasma cells and immunoglobulin kappa $\mathrm{C}$ indicates an important role of the humoral immune response in non-small cell lung cancer. Cancer Lett 333(2):222-228

57. Fujimoto M, Yoshizawa A, Sumiyoshi S, Sonobe M, Kobayashi M, Koyanagi I et al (2013) Stromal plasma cells expressing immunoglobulin G4 subclass in non-small cell lung cancer. Hum Pathol 44(8):1569-1576

58. Zhou J, Min Z, Zhang D, Wang W, Marincola F, Wang X (2014) Enhanced frequency and potential mechanism of B regulatory cells in patients with lung cancer. J Transl Med 11(12):304

59. Liu J, Wang H, Yu Q, Zheng S, Jiang Y, Liu Y et al (2016) Aberrant frequency of IL-10-producing B cells and its association with Treg and MDSC cells in non small cell lung carcinoma patients. Hum Immunol 77(1):84-89

60. Fillatreau S (2015) Regulatory plasma cells. Curr Opin Pharmacol 23:1-5

61. Blair PA, Noreña LY, Flores-Borja F, Rawlings DJ, Isenberg DA, Ehrenstein MR et al (2010) CD19+CD24hiCD38hi B cells exhibit regulatory capacity in healthy individuals but are functionally impaired in systemic lupus erythematosus patients. Immunity 32(1):129-140

62. Bosma A, Abdel-Gadir A, Isenberg DA, Jury EC, Mauri C (2012) Lipid-antigen presentation by $\mathrm{CD} 1 \mathrm{~d}(+) \mathrm{B}$ cells is essential for the maintenance of invariant natural killer $\mathrm{T}$ cells. Immunity 36(3):477-490

63. Shao Y, Lo CM, Ling CC, Liu XB, Ng KT-P, Chu ACY et al (2014) Regulatory B cells accelerate hepatocellular carcinoma progression via CD40/CD154 signaling pathway. Cancer Lett. 355(2):264-272

64. Olkhanud PB, Baatar D, Bodogai M, Hakim F, Gress R, Anderson RL et al (2009) Breast cancer lung metastasis requires expression of chemokine receptor CCR4 and regulatory T cells. Cancer Res 69(14):5996-6004

65. Wang WW, Yuan XL, Chen H, Xie GH, Ma YH, Zheng YX et al (2015) CD19+CD24hiCD38hiBregs involved in downregulate helper $\mathrm{T}$ cells and upregulate regulatory $\mathrm{T}$ cells in gastric cancer. Oncotarget 6(32):33486-33499

66. Qian L, Bian G-R, Zhou Y, Wang Y, Hu J, Liu X et al (2015) Clinical significance of regulatory B cells in the peripheral blood of patients with oesophageal cancer. Cent-Eur J Immunol 40(2):263-265

67. Wei X, Jin Y, Tian Y, Zhang H, Wu J, Lu W et al (2016) Regulatory B cells contribute to the impaired antitumor immunity in ovarian cancer patients. Tumour Biol J Int Soc Oncodev Biol Med 37(5):6581-6588

68. Zhang C, Xin H, Zhang W, Yazaki PJ, Zhang Z, Le K et al (2016) CD5 Binds to Interleukin-6 and Induces a Feed-Forward Loop with the Transcription Factor STAT3 in B Cells to Promote Cancer. Immunity 44(4):913-923

69. Lee-Chang C, Bodogai M, Martin-Montalvo A, Wejksza K, Sanghvi M, Moaddel R et al (2013) Inhibition of breast cancer metastasis by resveratrol-mediated inactivation of tumor-evoked regulatory B cells. J Immunol Baltim Md 1950 191(8):4141-4151
70. Yanaba K, Bouaziz J-D, Haas KM, Poe JC, Fujimoto M, Tedder TF (2008) A regulatory B cell subset with a unique CD1dhiCD5 + phenotype controls T cell-dependent inflammatory responses. Immunity 28(5):639-650

71. Mizoguchi A, Mizoguchi E, Takedatsu H, Blumberg RS, Bhan AK (2002) Chronic intestinal inflammatory condition generates IL-10-producing regulatory B cell subset characterized by CD1d upregulation. Immunity 16(2):219-230

72. Wang H-M, Zhang X-H, Feng M-M, Qiao Y-J, Ye L-Q, Chen J et al (2018) Interleukin-35 suppresses the antitumor activity of $\mathrm{t}$ cells in patients with non-small cell lung cancer. Cell Physiol Biochem 47(6):2407-2419

73. Pylayeva-Gupta Y, Das S, Handler JS, Hajdu CH, Coffre M, Koralov SB et al (2016) IL35-Producing B Cells Promote the Development of Pancreatic Neoplasia. Cancer Discov 6(3):247-255

74. Iwata Y, Matsushita T, Horikawa M, Dilillo DJ, Yanaba K, Venturi GM et al (2011) Characterization of a rare IL-10-competent B-cell subset in humans that parallels mouse regulatory B10 cells. Blood 117(2):530-541

75. Lindner S, Dahlke K, Sontheimer K, Hagn M, Kaltenmeier C, Barth TFE et al (2013) Interleukin 21-induced granzyme B-expressing B cells infiltrate tumors and regulate T cells. Cancer Res 73(8):2468-2479

76. van de Veen W, Stanic B, Yaman G, Wawrzyniak M, Söllner S, Akdis DG et al (2013) IgG4 production is confined to human IL-10-producing regulatory B cells that suppress antigen-specific immune responses. J Allergy Clin Immunol 131(4):1204-1212

77. Matsumoto M, Baba A, Yokota T, Nishikawa H, Ohkawa Y, Kayama $\mathrm{H}$ et al (2014) Interleukin-10-producing plasmablasts exert regulatory function in autoimmune inflammation. Immunity 41(6):1040-1051

78. Saze Z, Schuler PJ, Hong C-S, Cheng D, Jackson EK, Whiteside TL (2013) Adenosine production by human B cells and B cellmediated suppression of activated T cells. Blood 122(1):9-18

79. Liu J, Zhan W, Kim CJ, Clayton K, Zhao H, Lee E et al (2014) IL-10-producing B cells are induced early in HIV-1 infection and suppress HIV-1-specific T cell responses. PLoS ONE 9(2):e89236

80. Nouël A, Pochard P, Simon Q, Ségalen I, Le Meur Y, Pers JO et al (2015) B-Cells induce regulatory T cells through TGF- $\beta /$ IDO production in A CTLA-4 dependent manner. J Autoimmun 59:53-60

81. Zhang Y, Morgan R, Chen C, Cai Y, Clark E, Khan WN et al (2016) Mammary-tumor-educated B cells acquire LAP/TGF- $\beta$ and PD-L1 expression and suppress anti-tumor immune responses. Int Immunol 28(9):423-433

82. Yang C, Lee H, Pal S, Jove V, Deng J, Zhang W et al (2013) B Cells Promote tumor progression via STAT3 regulated-angiogenesis. Viola JPB, editor. PLoS One 8(5):e64159

83. Sarvaria A, Madrigal JA, Saudemont A (2017) B cell regulation in cancer and anti-tumor immunity. Cell Mol Immunol 14(8):662-674

84. Neyt K, Perros F, GeurtsvanKessel CH, Hammad H, Lambrecht BN (2012) Tertiary lymphoid organs in infection and autoimmunity. Trends Immunol 33(6):297-305

85. Litsiou E, Semitekolou M, Galani IE, Morianos I, Tsoutsa A, Kara P et al (2013) CXCL13 production in B cells via toll-like receptor/lymphotoxin receptor signaling is involved in lymphoid neogenesis in chronic obstructive pulmonary disease. Am $\mathbf{J}$ Respir Crit Care Med 187(11):1194-1202

86. Sautès-Fridman C, Cherfils-Vicini J, Damotte D, Fisson S, Fridman WH, Cremer I et al (2011) Tumor microenvironment is multifaceted. Cancer Metastasis Rev 30(1):13-25 
87. Wang Z, Cheng Q, Tang K, Sun Y, Zhang K, Zhang Y et al (2015) Lipid mediator lipoxin A4 inhibits tumor growth by targeting IL-10-producing regulatory B (Breg) cells. Cancer Lett 364(2):118-124

88. Damsky W, Jilaveanu L, Turner N, Perry C, Zito C, Tomayko $\mathrm{M}$ et al (2019) B cell depletion or absence does not impede antitumor activity of PD-1 inhibitors. J Immunother Cancer 7(1):153

89. Yuan J, Adamow M, Ginsberg BA, Rasalan TS, Ritter E, Gallardo HF et al (2011) Integrated NY-ESO-1 antibody and CD8 + T-cell responses correlate with clinical benefit in advanced melanoma patients treated with ipilimumab. Proc Natl Acad Sci USA 108(40):16723-16728

90. Varn FS, Wang Y, Cheng C (2019) A B cell-derived gene expression signature associates with an immunologically active tumor microenvironment and response to immune checkpoint blockade therapy. OncoImmunology 8(1):e1513440

91. Zhang M, Xia L, Yang Y, Liu S, Ji P, Wang S et al (2019) PD-1 blockade augments humoral immunity through ICOS-mediated CD4 + T cell instruction. Int Immunopharmacol 1(66):127-138

92. Achour A, Simon Q, Mohr A, Séité J-F, Youinou P, Bendaoud B et al (2017) Human regulatory B cells control the TFH cell response. J Allergy Clin Immunol 140(1):215-222

93. Khan AR, Hams E, Floudas A, Sparwasser T, Weaver CT, Fallon PG (2015) PD-L1hi B cells are critical regulators of humoral immunity. Nat Commun 6(1):5997

94. Schildberg FA, Klein SR, Freeman GJ, Sharpe AH (2016) Coinhibitory pathways in the B7-CD28 ligand-receptor family. Immunity 44(5):955-972

95. Thibult M-L, Mamessier E, Gertner-Dardenne J, Pastor S, JustLandi S, Xerri L et al (2013) PD-1 is a novel regulator of human B-cell activation. Int Immunol 25(2):129-137

96. Das R, Bar N, Ferreira M, Newman AM, Zhang L, Bailur JK et al (2018) Early B cell changes predict autoimmunity following combin. 128(2):715-720
97. Sowerby L, Dewan AK, Granter S, Gandhi L, LeBoeuf NR (2017) Rituximab treatment of nivolumab-induced bullous pemphigoid. JAMA Dermatol 153(6):603-605

98. Shaikh H, Daboul N, Albrethsen M, Fazal S (2018) A case of autoimmune haemolytic anaemia after 39 cycles of nivolumab. BMJ Case Rep 18:2018

99. Ito M, Fujiwara S, Fujimoto D, Mori R, Yoshimura H, Hata A et al (2017) Rituximab for nivolumab plus ipilimumab-induced encephalitis in a small-cell lung cancer patient. Ann Oncol 28(9):2318-2319

100. Shiuan E, Beckermann KE, Ozgun A, Kelly C, McKean M, McQuade J et al (2017) Thrombocytopenia in patients with melanoma receiving immune checkpoint inhibitor therapy. $\mathrm{J}$ Immunother Cancer. 5:8

101. Hasanov M, Konoplev SN, Hernandez CMR (2018) Nivolumabinduced cold agglutinin syndrome successfully treated with rituximab. Blood Adv 2(15):1865-1868

102. Mauri C, Menon M (2017) Human regulatory B cells in health and disease: therapeutic potential [Internet]. 2017 [cited 2019 Nov 4]. https://www.jci.org/articles/view/85113/pdf

103. Vansteenkiste JF, Cho BC, Vanakesa T, De Pas T, Zielinski M, Kim MS et al (2016) Efficacy of the MAGE-A3 cancer immunotherapeutic as adjuvant therapy in patients with resected MAGE-A3-positive non-small-cell lung cancer (MAGRIT): a randomised, double-blind, placebo-controlled, phase 3 trial. Lancet Oncol 17(6):822-835

Publisher's Note Springer Nature remains neutral with regard to jurisdictional claims in published maps and institutional affiliations. 